\title{
Tuberculosis treatment outcomes of non- citizen migrants: Israel compared to other high-income countries
}

\author{
D. Chemtob ${ }^{1,2^{*}}$ and E. Ogum ${ }^{2}$
}

\begin{abstract}
Background: In TB low incidence countries, the outcome of TB treatment among non-citizen migrants from endemic countries affects ability to eliminate TB. This study compares TB treatment outcomes among noncitizen migrants in select pre-elimination country based on their policies for non-citizen migrant TB patients in order to determine how policy affects TB outcomes.
\end{abstract}

Methods: A literature review was conducted via PUBMED, MEDLINE (2000-2017) on TB policy among non-citizen migrants and treatment outcome. Treatment outcome among migrants diagnosed in Israel during 2000-2014 was analysed.

Results: In total, 18 publications met the inclusion criteria. All the countries reviewed except the United States offered free TB treatment to undocumented migrants. Successful TB treatment outcome for non-citizen migrants in Israel was $87 \%$, the Netherlands was $90.7 \%$, the UK was $82.1 \%$, and outcomes in the US and Australia were not published.

Conclusions: There is a need to standardize results based on international definitions of migrants, asylum seekers, and refugees in order to determine status-specific barriers and to facilitate international comparisons. Policies insuring free access to TB care for non-citizen migrants are an important element for TB elimination in low incidence countries.

Keywords: Comparative study, Migrant health, Tuberculosis

\section{Introduction}

Immigration policies and shifting migration patterns over the past five decades have brought larger numbers of permanent and temporary migrants from regions of the world with a high incidence of active TB to areas with a low incidence [1]. Nearly $50 \%$ of TB cases in lowincidence countries are among foreign-born residents and citizens [1]. Among the 33 countries defined as being in the pre-elimination phase by the WHO in 2015, the proportion of foreign-born TB cases notified in 2012

\footnotetext{
* Correspondence: daniel.chemtob@moh.gov.il

'Department of Tuberculosis and AIDS, Ministry of Health, P.O.B. 1176, 944727 Jerusalem, Israel

${ }^{2}$ Braun School of Public Health and Community Medicine, Hebrew University of Jerusalem, Jerusalem, Israel
}

(c) The Author(s). 2020 Open Access This article is licensed under a Creative Commons Attribution 4.0 International License, which permits use, sharing, adaptation, distribution and reproduction in any medium or format, as long as you give appropriate credit to the original author(s) and the source, provide a link to the Creative Commons licence, and indicate if changes were made. The images or other third party material in this article are included in the article's Creative Commons licence, unless indicated otherwise in a credit line to the material. If material is not included in the article's Creative Commons licence and your intended use is not permitted by statutory regulation or exceeds the permitted use, you will need to obtain permission directly from the copyright holder. To view a copy of this licence, visit http://creativecommons.org/licenses/by/4.0/. The Creative Commons Public Domain Dedication waiver (http://creativecommons.org/publicdomain/zero/1.0/) applies to the data made available in this article, unless otherwise stated in a credit line to the data.

for selected countries were as followed: Israel - 90\%; Australia - 87\%; The Netherlands - 73\%; and the USA - 63\% [2]. The United Kingdom, while not in the preelimination phase, has $73 \%$ of tuberculosis incidence among foreign-born migrants. However, policies regarding TB management for migrants in these countries are not clearly stated, especially for migrants without official legal status [1].

Trends in foreign-born TB cases vary across countries. In Israel, studies focused on migrants who obtained Israeli citizenship, as non-citizen migrants were a marginal proportion of the population prior to mass migration from high-endemic countries beginning in 2006 [3-6]. Australia's proportion of TB in foreign-born people has risen steadily over the past 15 years, despite 
decreases in overall incidence [2, 7]. Since 2000, migrants to Australia have contributed to more than $80 \%$ of TB cases [2,7]. In the Netherlands, TB incidence is closely linked to the inflow of migrants and asylumseekers $[8,9]$. TB cases reported in the UK were 15 times higher among foreign-born migrants than the UKborn population [10]. In 2016, foreign-born individuals accounted for $66.2 \%$ of the reported cases in the US [11]. In the same year, the US saw an increase in the number of $\mathrm{TB}$ cases, the second time in 23 years the rate did not decline.

In these countries, migration presents a significant challenge for TB surveillance and control, particularly due to the tentative or undocumented status of many migrants. Subsequently, data specific to undocumented migrants are often missing or underestimated. Policies in low TB incidence countries are often imprecise concerning care for undocumented migrants, and sometimes for refugees, asylum seekers, and otherwise classified migrants [11-13]. In this study, we explore the current policies of five high-income countries regarding TB patients who are non-citizens of these countries.

\section{Definitions}

Definitions related to migrants used in this article are similar to the ones used elsewhere as defined by specialized international organizations $[14,15]$. The overall definition of a migrant is 'any person who is moving or has moved across an international border or within a State away from his/her habitual place of residence, regardless of 1 ) the person's legal status; 2) whether the movement is voluntary or involuntary; 3) what the causes for the movement are; or 4) the length of the stay' $[14,15]$. 'Undocumented migrants' were defined as migrants who do not have the necessary documentation to enter or remain legally in a country $[14,15]$. An 'asylum seeker' was defined as a person who seeks safety from persecution or serious harm in a country other than his or her own and awaits a decision on the application for refugee status. A 'refugee' was defined as a person who has been forced to flee his or her country because of persecution, war or violence and seeks protection in another country [14, 15].

In order to encompass both documented migrants without citizenship (such as labor migrants, asylum seekers, and refugees) and undocumented migrants, we use the term "non-citizen migrants" in this article.

Pre-elimination for TB has been defined by several international bodies, including the WHO. Until 2035, the WHO global strategy milestone for TB elimination is 10 cases per 100,000 people [2].

However, for pre-elimination countries $(<100$ cases per million population), this definition is irrelevant. The current goal for such countries is less than 1 smearpositive case per million population [2].

Treatment success for treatment-sensitive cases was defined as a patient who completed treatment and who either had a smear or culture negative test or who completed treatment but did not undergo a smear or culture test in the last month [3].

\section{Methods}

Five high-income countries, 4 of which had a significant proportion of foreign-born cases as notified in 2012 were selected, and a search of multiple databases (The Cochrane Database of Systematic Reviews, MEDLINE and EMBASE) was conducted in order to identify relevant articles on TB control policy among non-citizen migrants and TB treatment outcome published between January 2000 to August 2017. We used keywords in various combinations: 'tuberculosis OR TB' AND 'Non-citizen' OR 'undocumented migrants' OR 'migrants' OR 'refugees' OR 'asylum seekers' OR 'foreign-born' AND 'policy'. Articles for which at least an English abstract was available were included.

In addition, TB treatment outcome among migrants diagnosed in Israel for the years 2000-2014 were analysed retrospectively. Data were used from the Israeli National Registry of TB at the Department of Tuberculosis and AIDS, Ministry of Health (MoH). Data from the 4 other countries for similar years were extracted from the literature or were sought through contacting medical officers in charge of TB control and/or surveillance in these countries (Dr. Gerard de Vries for the Netherlands \& Dr. Maeve Lalor for the UK), and/or through the national website (for Australia and US). Incidence rate and TB outcomes were also determined. The data obtained were analyzed using IBM SPSS version 20.

\section{Results}

Three hundred and nineteen articles and abstracts written in English, French, Spanish, Italian and Portuguese were considered. After screenings of the titles and abstracts, 59 studies were reviewed and 18 articles were used to generate the results (see Table 1 \& Fig. 1). Articles that were not focused on TB Policy were excluded.

\section{Policy recommendations}

As of 2014, universal health coverage policies and regulatory frameworks for $\mathrm{TB}$ notification were recommended by the WHO end-TB strategy. In this recommendation, it was emphasized that $\mathrm{TB}$ diagnosis and treatment must be free of charge for all migrants irrespective of a patient's legal status in the country $[24,27]$ 
Table 1 Articles reviewed on TB control policy among migrants in relation to the selected countries

\begin{tabular}{|c|c|c|c|c|}
\hline Authors & $\begin{array}{l}\text { Year of } \\
\text { publication }\end{array}$ & Study design & Receiving country & Reference \\
\hline Alvarez GG. et al & 2011 & Descriptive study of immigration TB screening programs & $\begin{array}{l}\text { EU/EEA \& Non-EU/ } \\
\text { EEA }\end{array}$ & [16] \\
\hline Chemtob D. et al & 2003 & Policy and Record review & Israel & [3] \\
\hline Chemtob D. et al & 2003 & Retrospective cohort analysis and Interview & Israel & [4] \\
\hline Chemtob D. et al & 2015 & Retrospective analysis and records review & Israel & {$[17]$} \\
\hline Correa-Velez I. et al & 2005 & Policy review & Australia & [18] \\
\hline Dara M. et al & 2012 & Systematic review & $\begin{array}{l}\text { EU/EEA \& Non-EU/ } \\
\text { EEA }\end{array}$ & [11] \\
\hline Dara M. et al & 2016 & Cross-sectional study & EU/EEA & [12] \\
\hline Dara M. et al & 2017 & Non-systematic literature review & $\begin{array}{l}\text { EU/EEA \& Non-EU/ } \\
\text { EEA }\end{array}$ & [19] \\
\hline Eziefula AC. et al & 2014 & Retrospective records review & UK & [20] \\
\hline Hodge JG. et al & 2009 & Policy review & USA & [21] \\
\hline Kik SV. et al & 2009 & A cross-sectional survey & The Netherlands & [22] \\
\hline Kronfol NM. et al & 2013 & Retrospective records review & $\begin{array}{l}\text { EU/EEA \& Non-EU/ } \\
\text { EEA }\end{array}$ & {$[1]$} \\
\hline Kunst H. et al & 2017 & Systematic review & EU & [13] \\
\hline La'Marcus TW. et al & 2015 & Retrospective records review and Cost-effectiveness & USA & [23] \\
\hline Lönnroth K. et al & 2015 & $\begin{array}{l}\text { A narrative review of WHO policy documents and guidelines, as well as } \\
\text { published literature }\end{array}$ & $\begin{array}{l}\text { EU/EEA \& Non-EU/ } \\
\text { EEA }\end{array}$ & [2] \\
\hline Lönnroth K. et al & 2017 & A narrative literature review and secondary data analyses & $\begin{array}{l}\text { EU/EEA \& Non-EU/ } \\
\text { EEA }\end{array}$ & [24] \\
\hline Odone A. et al & 2014 & Comprehensive literature review & EU/EEA & {$[25]$} \\
\hline $\begin{array}{l}\text { van den Bosch C. } \\
\text { et al }\end{array}$ & 2000 & Retrospective records review & UK & [26] \\
\hline
\end{tabular}

\section{National Policy: Israel}

Since 1997, the National TB Control Programme has provided diagnosis and treatment to patients with $\mathrm{TB}$ without charge regardless of citizenship or migration status [4, 17]. For all TB cases, an epidemiological enquiry is performed for active case finding among close contacts of the diagnosed patient $[16,17]$.

\section{National Policy: Australia}

TB treatment is available without charge to patients and does not require insurance. Tuberculosis screening is a prerequisite for obtaining a visa, and if an individual has active TB, entry into the country will not be granted [7].

\section{National policy: the Netherlands}

The Netherlands' policies are dependent on migration type, though treatment is available without charge for all persons notified in the Netherlands. Immigrants from high TB-incidence countries who intend to stay more than 3 months are referred by the immigration office to the municipal health service for screening, which is continued at 6-month intervals for 2 years [1, 12].
Asylum seekers from high TB incidence countries are screened upon arrival at dedicated reception centres.

The Immigration Act stipulates that undocumented migrants with TB can stay in the Netherlands for the duration of their treatment. Housing, health insurance and the costs of living are covered during this period [12].

\section{National policy: United Kingdom}

In the UK, pre-entry screening for active TB based on clinical evaluation and CXR is required for all individuals applying for a UK visa longer than 6 months. This is accomplished through a preemigration procedure in the country of origin or transit of the migrant [12].

Currently, asylum seekers and refugees are entitled to free primary and secondary care. Asylum seekers and undocumented migrants have access to limited NHS care; they are entitled to free primary care at the discretion of the health care provider but have to pay for secondary care. Frequently, they are denied free universal access to TB care $[20,28]$. 


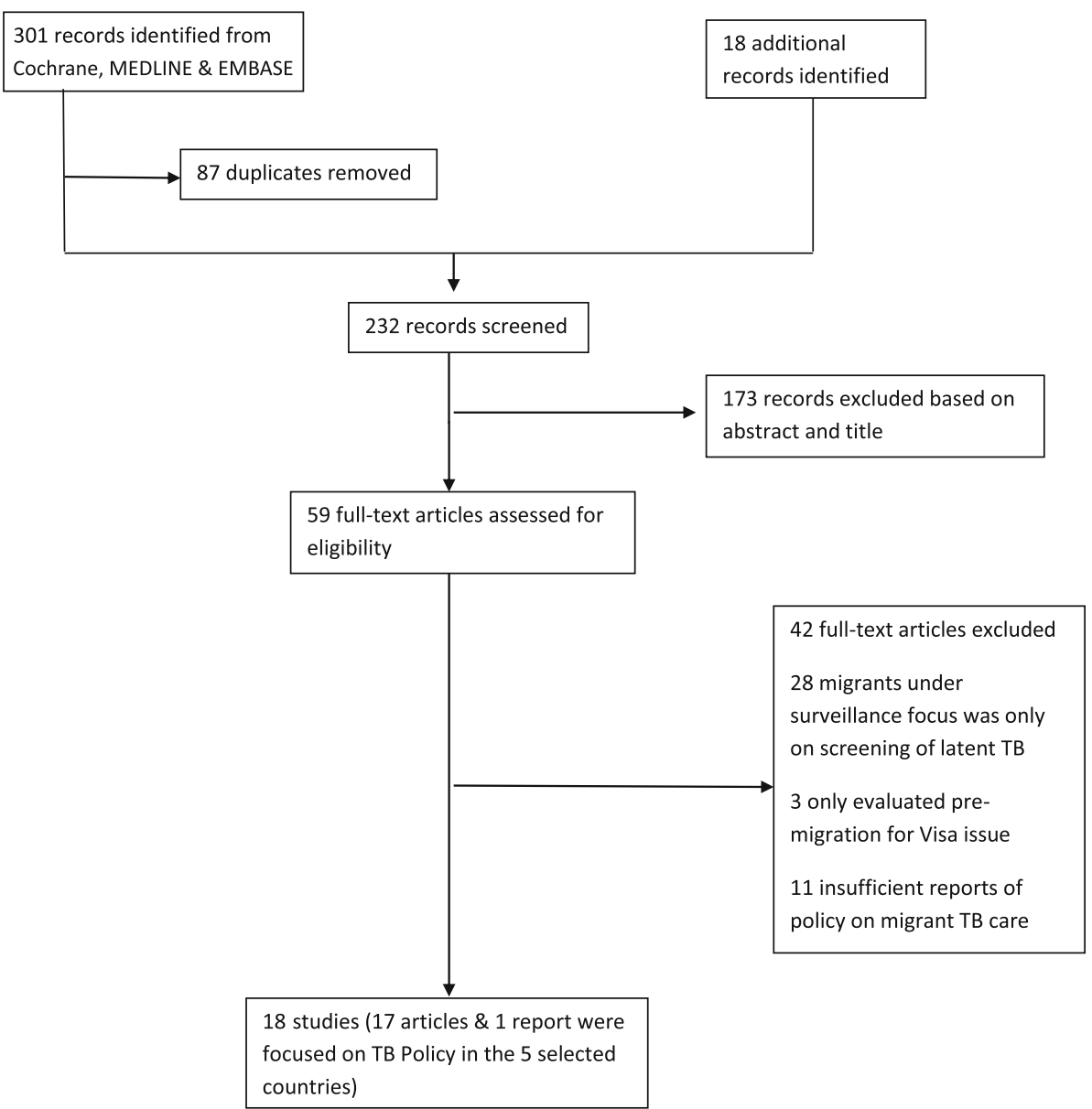

Fig. 1 Literature selection search on TB policy for the non-citizens of the 5 selected western countries (Australia, Israel, The Netherlands, UK and USA)

\section{National policy: United States}

Unlike the other countries in this review, the United States does not have a universal healthcare system, which limits access to non-citizen migrants, particularly those without employment or legal status [12]. Though the Advisory Council for the Elimination of Tuberculosis (ACET), which does not implement official US regulations, recommends that a lack of health insurance should not be a condition for the timely initiation of appropriate TB treatment it is not clear how this policy is implemented for migrants, particularly the undocumented, across states. The ACET recommendations also state that state health departments can request reimbursement from third-party payers [29]. Following the passage of the Affordable Care Act, which guaranteed TB care to all citizens as part of a national health coverage scheme, some researchers have noted that this coverage does not extend to undocumented migrant groups [30, 31].

The U. S request for pre-entry examinations for those planning a stay of more than six months [23, 32]. Those declared refugees are eligible for Medicaid, state-funded subsidized insurance, for the first eight months after their arrival in most states, and can assess TB care through this program $[23,32]$.

\section{TB incidence among non-citizen migrants}

The annual incidence rate for TB among non-citizen migrants declined across all the countries included in the study, between $28.8 \%$ in the United Kingdom to only $10.7 \%$ decline in the United States. Additional details shown in Table 2.

\section{Characteristics of all TB cases among non-Israeli citizens in Israel}

Out of the 6321 cases of TB notified in Israel between 2000 and 2014, 1580 were non-citizen migrants (25.6\%). 1556 cases were included in the analysis, and incomplete files were not included (98.5\%). The sex ratio for the male to female patients was 2:1. Migrants originated from the Horn of Africa (56.2\%), Asia (25.5\%), Eastern Europe (7.3\%), other sub-Saharan African countries (3.9\%), and other countries (7.1\%). For most migrants, TB was diagnosed within two years from arrival (70.4\%). 
Table 2 Incidence of tuberculosis (per 100,000 people) among non-citizen migrants, by country and by notification year

\begin{tabular}{llll}
\hline Country & \multicolumn{3}{l}{ TB among non-citizen migrants } \\
\cline { 2 - 4 } & 2000 & 2015 & $\%$ Decrease \\
\hline Australia & 18.0 & 16.1 & 10.5 \\
Israel & 40.0 & 11.4 & 71.5 \\
The Netherlands & 61.0 & 33.8 & 44.6 \\
United Kingdom & 80.0 & 51.2 & 36.0 \\
United States & 25.8 & 15.1 & 41.5 \\
Ref: $[2,4,8,10,19,22,25,33-35]$ & & \\
\hline
\end{tabular}

\section{Treatment outcomes of non-citizen migrants}

In Israel, the percentage of TB patient who completed treatment was $47.5 \%$ and the percentage cured was $39.5 \%$, meaning the overall success rate was $87 \%(n=$ 1354).

The treatment success rate was $87.9 \%$ among nonHIV infected TB patients in contrast to $71.8 \%$ among HIV co-infected TB patients (OR: 3.025; CI: 1.5825.786) (Table 3).

Of other countries included in the study, only two could provide data on treatment success for non-citizen migrants; in the Netherlands, $90.7 \%$ of TB outcomes were successful (personal communication, Dr. Gerard de Vries, KNCV Tuberculosis Foundation). In the UK, $82.1 \%$ of TB outcomes among non-citizen migrants were successful (personal communication, Dr., Maeve Lalor, Public Health England).

\section{Discussion}

A major finding in the literature was the insufficient TB data on non-citizen migrants and the difficulty of stating clearly the distinction between a non-citizen migrant and a foreign-born migrant, and different application of these definitions across countries. Most of the literature focused on data on the foreign-born ignoring the possibility that some foreign-born could be eligible for citizenship on arrival or after several years in the low incidence TB country. This could be partly explained by the logistic difficulties of distinguishing between documented and undocumented migrants, which are often coupled with legal national restrictions concerning identified notifications [24].

In Israel, most non-citizen migrant TB patients originate from the Horn of Africa. This was also similar to the findings of previous studies which detected a significant increase of $\mathrm{TB}$ in immigrants who migrate to high-income countries [36]. We observed differences $(p<0.05)$ in the HIV infection and TB in migrants in Israel with migrants from African regions being the highest. Similar findings were seen in a previous study in the UK [36].

From 2000 to 2015, incidence rates of TB among noncitizen migrants fell between $10.5-71.5 \%$ in the countries of study. Across all the countries under study, Israel reported the lowest $\mathrm{TB}$ incidence rate among migrants and the UK reported the highest at the end of 2015. This low incidence rate was achieved despite Israel having the third lowest incidence rate among migrants in 2000. It's important to note that, in addition to meeting the preelimination target during the years of study in the total population, Israel neared this target in the non-citizen migrant sub-population. Direct comparisons between countries must be made with caution, as the characteristics and health determinants of persons screened vary by both by country of origin and destination.

The successful outcome of TB treatment among noncitizens migrants may be attributable to the policy in

Table 3 Overall outcome of treatment according to demographic origin and risk factors of non-Israeli citizens in Israel; 2000-2014

\begin{tabular}{|c|c|c|c|c|c|c|}
\hline \multirow[t]{2}{*}{ Variable } & & \multicolumn{2}{|c|}{ Treatment Success } & \multirow[t]{2}{*}{ Total } & \multirow[t]{2}{*}{ OR } & \multirow[t]{2}{*}{$95 \% \mathrm{Cl}$} \\
\hline & & No n(\%) & Yes n(\%) & & & \\
\hline \multirow[t]{3}{*}{ Sex } & Male & $138(13.2)$ & $905(86.8)$ & 1043 & 0.491 & {$[0.315-0.764]$} \\
\hline & Female & $64(12.5)$ & $449(87.5)$ & 513 & - & - \\
\hline & Overall & $202(13.0 \%)$ & $1354(87.0 \%)$ & 1556 & & \\
\hline \multirow[t]{5}{*}{ Region } & Horn of Africa & $63(7.2)$ & $812(92.8)$ & 875 & 4.006 & [1.810-8.870] \\
\hline & Asia & $64(16.1)$ & $333(83.9)$ & 397 & 1.096 & [0.492-2.439] \\
\hline & Sub-Saharan & $15(24.6)$ & $46(75.4)$ & 61 & 0.880 & {$[0.333-2.325]$} \\
\hline & Eastern Europe & $40(35.4)$ & $73(64.6)$ & 113 & 0.556 & {$[0.236-1.311]$} \\
\hline & Other & $20(18.2)$ & $90(81.8)$ & 110 & - & - \\
\hline \multirow[t]{2}{*}{ Length of Stay } & $<2 \mathrm{yrs}$ & $98(11.7)$ & $743(88.3)$ & 841 & 0.829 & [0.542-1.269] \\
\hline & $>2$ yrs & $42(11.9)$ & $312(88.1)$ & 354 & - & - \\
\hline \multirow[t]{2}{*}{ HIV Status } & Negative & $179(12.1)$ & 1296 (87.9) & 1475 & 3.025 & {$[1.582-5.786]$} \\
\hline & Positive & $22(28.2)$ & $56(71.8)$ & 78 & - & - \\
\hline
\end{tabular}


various countries. However, not all countries under the current study could provide data on non-citizen migrant treatment outcomes. Countries who could provide this data also had migrant-friendly TB policies, with the most success in the Netherlands, where social assistance is provided to $\mathrm{TB}$ patients during their treatment. Additional social welfare may explain why TB treatment outcome in the Netherlands is higher than other countries under study.

WHO has emphasized that TB diagnosis and treatment must be free of charge for all migrants [2, 17]. This has guided some low-incidence countries to have lowcost or free TB treatment. However, problems for migrants to access treatment persist. Some low-incidence countries do not provide free TB care at a national level, as is the case in the US $[2,11]$. In the UK, undocumented migrants may be excluded from national health services or insurance schemes, which limits overall service access. Moreover, while access to TB is universally accessible on paper in the UK, other important barriers can restrict access and adherence, including language, stigma, and discrimination [2]. In The Netherlands, where health insurance is available for non-citizen migrants, co-payments can constitute financial barriers for some.

Migrants in the US do not have completely free access to TB care and are provided treatment at a cost to the individual either as co-payment where health insurance is made available or out of pocket spending $[12,33,37$, 38]. This may discourage migrants who do not have a source of income to start treatment when diagnosed with active $\mathrm{TB}$, especially migrants who are not legal residents in the country $[2,33]$.

In addition to policy and other barriers in the countries in the present study, the WHO notes further barriers for migrants in accessing TB care, including fear of being reported to migration officials and/or deported during treatment [24].

Interestingly, Israel created this policy over a decade before the WHO recommendation. This may greatly contribute to the success of TB control in this country $[4,22,27]$. The percentage of successful treatment outcome in Israel was high, particularly for a population considered difficult to reach [4]. The early implementation of a care-for-all strategy for TB may have contributed to the high rate of successful treatment among non-citizen migrants.

\section{Limitations of the study}

Data quality is primarily the responsibility of every country. The study data from Israel includes secondary data analysis from the National TB program; minimal errors could have occurred during data entry and computations but would not have affected the study's results. Other countries' data were from the literature, $\mathrm{KNCV}$, and unpublished data from Public Health England, which were analysed by local experts. Also, the periods of years reviewed were not uniform. Hence, our results might not provide a complete or uniform picture of TB among non-citizen migrants across. Furthermore, TB outcome of treatment among immigrants could not be calculated in some selected countries due to the unavailability of non-citizen migrant population data.

\section{Strengths of the study}

To the best of our knowledge, the study is the first formal effort to articulate TB policy and subsequent treatment outcomes of non-citizen migrants in the low incidence countries.

\section{Conclusion and recommendations}

Lack of data on the outcome of TB treatment among non-citizens in the selected countries is a drawback to describing the relationship of each countries policy with respect to the treatment outcome. The US was the only country under this study that does not have a national policy for universal TB care, though many individual states within the US do extend no or low cost TB care. This study supports that TB policies that extend care to non-citizen migrants, including the undocumented, is essential for TB elimination. Moreover, this study highlighted the difficulties of researching TB among non-citizen migrants, as countries operate on their own definitions of migration and citizen type. There is a global need to standardize the definitions of migrants for research purposes. Israel's trailblazing policy to provide TB care regardless of citizenship status extended care to a large percentage of the TB case load. Following the Netherlands' model, TB treatment success among this population in Israel may benefit from additional social assistance during treatment to increase compliance and ability to complete treatment, including housing and cost of living.

\section{Acknowledgements \\ We would like to thank Ms. Jordan Hannink for her editorial assistance. We would like to thank Ms. Miri Yehuda from the Department of Tuberculosis and AIDS, for her support in data collection and management, and Dr. Dennis Falzon from WHO-Geneva, for having referred the medical officers in charge of TB surveillance in the selected countries, including Drs. Gerard de Vries (KNCV Tuberculosis Foundation, the Netherlands), and Maeve Lalor (Public Health England on TB).}

\section{Authors' contributions}

Dr. Chemtob as a Senior Lecturer at the Hebrew University School of Public Health, initiated the design of the research, supervised the work done by Dr. Emmanuel Ogum, as an international MPH student, provided the data from the DTA, designed the original concept of this article, helped in analyzing, structuring and interpreting the data, and significantly participated in the writing of the manuscript. Dr. Emmanuel Ogum, MD, MPH, was an international MPH student at the School of Public Health, Hebrew University, and performed his MPH thesis on this topic. He acquired the original data set from the Ministry of Health and spearheaded the collection of data on 
the additional variables. He participated in the design of the original concept of this article, analysis of the data, and significantly participated in the writing of the manuscript. The author(s) read and approved the final manuscript.

\section{Funding}

This publication did not receive any form of funding from any source.

\section{Data availability statement}

This material could be obtained from the corresponding author if the request is in accordance to the Israeli Ministry of Health requirements.

\section{Ethical approval and consent to participate}

For this type of retrospective study, using data collected for surveillance purpose, formal consent is not required.

\section{Consent for publication}

Not applicable.

\section{Competing interests}

The authors declare that they have no competing interests.

Received: 22 January 2020 Accepted: 26 May 2020

Published online: 03 August 2020

\section{References}

1. Kronfol N, Mansour Z. Tuberculosis and migration: a review/Tuberculose et migration: analyse. East Mediterr Health J. 2013;19(8):739.

2. Lönnroth K, Migliori GB, Abubakar I, D'Ambrosio L, De Vries G, Diel R, et al. Towards tuberculosis elimination: an action framework for low-incidence countries. Eur Respir J. 2015;45(4):928-52.

3. Chemtob D, Leventhal A, Berlowitz Y, Weiler-Ravell D. The new National Tuberculosis control programme in Israel, a country of high immigration. Int J Tuberc Lung Dis. 2003;7(9):828-36

4. Chemtob D, Leventhal A, Weiler-Ravell D. Screening and management of tuberculosis in immigrants: the challenge beyond professional competence. IJTLD. 2003:7(10):959-66.

5. Heldal E, Kuyvenhoven J, Wares F, Migliori G, Ditiu L, Fernandez De La Hoz $\mathrm{K}$, et al. Diagnosis and treatment of tuberculosis in undocumented migrants in low-or intermediate-incidence countries [workshop report]. IJTLD. 2008; 12(8):878-88.

6. Mor Z, Kolb H, Lidji M, Migliori G, Leventhal A. Tuberculosis diagnostic delay and therapy outcomes of non-national migrants in Tel Aviv, 1998-2008. Eurosurveillance. 2013;18(12):e20433.

7. Australian Government Department of Health. The strategic plan for control of Tuberculosis in Australia: 2011-2015. 2012. Available from: https://www1. health.gov.au/internet/main/publishing.nsf/Content/cda-cdi3603i.htm.

8. de Vries G, Riesmeijer R. National Tuberculosis Control Plan 2016-2020: Towards elimination. The National Institute for Public Health and the Environment. 2015. The Netherlands. Available from: https://www.rivm.nl/ bibliotheek/rapporten/2016-0012.pdf.

9. de Vries G, van Hest R, Bakker M, Erkens C, van den Hof S, Meijer W, et al. Policy and practice of programmatic management of latent tuberculosis infection in the Netherlands. J Clin Tuberc Other Mycobact Dis. 2017;7:40-8.

10. Public Health England. Tuberculosis in England 2016 Report. 2016. Available from: https://www.tbalert.org/wp-content/uploads/2016/09/PHE_TB_ Annual_Report_2016.pdf. Date Accessed: 30 April 2017.

11. Dara M, Sulis G, Centis R, D'Ambrosio L, De Vries G, Douglas P, et al. Crossborder collaboration for improved tuberculosis prevention and care: policies, tools and experiences. IJTLD. 2017;21(7):727-36.

12. Dara M, Solovic I, Sotgiu G, D'Ambrosio L, Centis R, Tran R, et al. Tuberculosis care among refugees arriving in Europe: an ERS/WHO Europe region survey of current practices. Eur Respir J. 2016;48(3):808-17.

13. Kunst $H$, Burman M, Arnesen $T$, Fiebig L, Hergens M, Kalkouni O, et al. Tuberculosis and latent tuberculous infection screening of migrants in Europe: a comparative analysis of policies, surveillance systems and results. IJTLD. 2017;21(8):840-51.

14. Zimmerman C, Kiss L, Hossain M. Migration and health: a framework for 21st-century policy-making. PLoS Med. 2011;8(5):e1001034.

15. UNESCO. Glossary of Migration Related Terms. UNESCO Paris. 2011. Available from: https://wayback.archive-it.org/10611/20180705022135/http:// www.unesco.org/new/en/social-and-human-sciences/themes/internationalmigration/glossary/. Date Accessed: 30 April 2017.

16. Alvarez GG, Gushulak B, Rumman KA, Altpeter E, Chemtob D, Douglas P, et al. A comparative examination of tuberculosis immigration medical screening programs from selected countries with high immigration and low tuberculosis incidence rates. BMC Infect Dis. 2011;11(1):3.

17. Chemtob D, Mor Z, Grotto I. Tuberculosis screening programmes for migrants to low-incidence countries - the Israeli experience. Lancet Infect Dis. 2015;15(8):876.

18. Correa-Velez I, Gifford SM, Bice SJ. Australian health policy on access to medical care for refugees and asylum seekers. Aust N Z Health Policy. 2005; 2(1):23.

19. Odone A, Tillmann T, Sandgren A, Williams G, Rechel B, Ingleby D, et al. Tuberculosis among migrant populations in the European Union and the European economic area. Eur J Pub Health. 2014;25(3):506-12.

20. Eziefula AC, Sa M, Brown M. The health of recent migrants from resourcepoor countries. Medicine. 2014;42(2):112-7.

21. Hodge JG. Tuberculosis control Laws and Policies: 2009. Available from: https://www.cdc.gov/tb/programs/tblawpolicyhandbook.pdf.

22. European Centre for Disease Prevention and Control. Surveillance of Tuberculosis in Europe. 2008. Available from: http://www.euro.who.int/ data/assets/pdf_file/0007/78856/E93600.pdf. Date Accessed: 30 April 2017.

23. La'Marcus TW, Coleman MS, de la Motte HC, Semple M, Zhou W, Cetron MS, et al. A cost-benefit analysis of a proposed overseas refugee latent tuberculosis infection screening and treatment program. BMC Pub Health. 2015;15(1):1201

24. Lönnroth K, Mor Z, Erkens C, Bruchfeld J, Nathavitharana R, van der Werf M, et al. Tuberculosis in migrants in low-incidence countries: epidemiology and intervention entry points. IJTLD. 2017;21(6):624-36.

25. Center for Disease Control. Tuberculosis Morbidity Among U.S.-Born and Foreign-Born Populations --- United States, 2000-2002. 2002. Available from: https://www.cdc.gov/mmwr/preview/mmwrhtml/mm5105a3.htm. Date Access: 30 April 2017.

26. Van den Bosch C, Roberts J. Tuberculosis screening of new entrants; how can it be made more effective? J Public Health. 2000;22(2):220-3.

27. World Health Organization. Excutive Board 134. Global strategy and targets for tuberculosis prevention, care and control after 2015. Draft resolution proposed by Australia, Brazil, Colombia, Costa Rica, Estonia, France, Italy, Japan, Netherlands, Poland, Portugal, Slovakia, South Africa, and the United States of America. 2014. Available from: https://apps.who.int/iris/handle/1 0665/172989. Date accessed 30 Apr 2017.

28. Eziefula C, Brown M. The health of recent migrants from resource-poor countries. Medicine. 2010;38(1):60-5.

29. Advisory Council for the Elimination of Tuberculosis. Centers for Disease Prevention and Control Website: Menu of Suggested Provisions for State Tuberculosis Prevention and Control Laws. 2020. Accessed on 20 Feb 2020. Available from: https://www.cdc.gov/tb/programs/laws/menu/ costs.htm.

30. Balaban, V. Marks, S. Etkind, S. Katz, D. Higashi, J. Flood, J. et. al. Tuberculosis elimination efforts in the United States in the era of insurance expansion and the affordable care act. Publc Health Reports 2015. 190 (July-August 2015): 349-354

31. Davidow, A. Katz, D. Ghosh, S. Blumberg, H. Tamhane, A. Sevilla, A. et. al. Preventing Infectious Pulmonary Tuberculosis Among Foreign-Born Residents of the United States. Am J Public Health. 105(9):e81-e88.

32. United States Department of Health and Human Services. Office of Refugee Resettlement: Health Insurance. 2015. Available from https://www.acf.hhs. gov/orr/health. Date Accessed: 10 July 2017.

33. Dara M, De Colombani P, Petrova-Benedict R, Centis R, Zellweger J-P, Sandgren A, et al. Minimum package for cross-border TB control and care in the WHO European region: a Wolfheze consensus statement. Eur Respir J. 2012;40(5):1081-90.

34. World Bank. Data from World Bank. Data on Incidence of tuberculosis (per 100,000 people). 2016. Available from: http://data.worldbank.org/indicator/ SH.TBS.INCD.

35. Borgdorff MW, Van der Werf MJ, De Haas PE, Kremer $K$, Van Soolingen D. Tuberculosis elimination in the Netherlands. Emerg Infect Dis. 2005 11(4):597.

36. Bothamley GH, Kruijshaar ME, Kunst H, Woltmann G, Cotton M, Saralaya D, et al. Tuberculosis in UK cities: workload and effectiveness of tuberculosis control programmes. BMC Pub Health. 2011;11(1):896. 
37. Kik SV, Olthof SP, de Vries JT, Menzies D, Kincler N, van LoenhoutRooyakkers J, et al. Direct and indirect costs of tuberculosis among immigrant patients in the Netherlands. BMC Pub Health. 2009;9(1):283.

38. Spencer J, Lin M, Roche P, McKinnon M. Tuberculosis notifications in Australia, 2000. Commun Dis Intell Q Rep. 2002;26(2):214.

\section{Publisher's Note}

Springer Nature remains neutral with regard to jurisdictional claims in published maps and institutional affiliations.

Ready to submit your research? Choose BMC and benefit from:

- fast, convenient online submission

- thorough peer review by experienced researchers in your field

- rapid publication on acceptance

- support for research data, including large and complex data types

- gold Open Access which fosters wider collaboration and increased citations

- maximum visibility for your research: over $100 \mathrm{M}$ website views per year

At $B M C$, research is always in progress.

Learn more biomedcentral.com/submissions 